\title{
Evaluation of the Folin-Ciocalteu Method and Quantification of Total Tannins in Stem Barks and Pods from Libidibia ferrea (Mart. ex Tul) L. P. Queiroz
}

\author{
Marcos Aurelio Morais Galvão ${ }^{1,2}$, Alice Oliveira de Arruda ${ }^{1}$, Isabelle Cristinne Ferraz \\ Bezerra $^{1,2}$, Magda Rhayanny Assunção Ferreira ${ }^{1,2}$, Luiz Alberto Lira Soares ${ }^{1,2 *}$ \\ ${ }^{1}$ Laboratório de Farmacognosia, Department of Pharmaceutical Sciences, Universidade Federal de Pernambuco - \\ Recife, Pernambuco, Brasil; ${ }^{2}$ Programa de Pós-Graduação em Inovação Terapêutica - PPGIT, Universidade \\ Federalde Pernambuco - Recife, Pernambuco, Brazil.
}

\begin{abstract}
The stem bark and pods of "juca'" are widely used in Brazilian folk medicine and, despite their therapeutic relevancies, there are insufficient reports about their quality control. Both herbal drugs from the species are rich in tannins, which showed a lot of biological and economic interest. Thus, the purpose of this study was to evaluate the method for quantification of tannins in the stem bark and pods from L. ferrea. The performance of the method was tested against the influence of the most relevant parameters (reaction time; amount of drug; type and amount of precipitationagents; and, concentration of the reagents). The procedure was validated according to the literature. After optimization, the experimental conditions were established as: 30 min of reaction; $\lambda$ of $760 \mathrm{~nm} ; 1.0 \mathrm{~mL}$ of Folin-Ciocalteu; $29 \%$ of $\mathrm{Na} 2 \mathrm{CO} 3$ (w/v); and, skin powder as complexion agent. The method validation showed that the instrumental response was linear and sensitive to the investigated analyte. The method presented the necessary precision (RSD < $2.19 \%)$ and accuracy (96.84\%-109.13\%), as recommended by the official codex. Moreover, the deliberate introduction of experimental variations showed the stability of the procedure error against external sources $(R S D<2.42 \%)$. In conclusion, the data demonstrated the suitability of the method and can be used as anappropriate analytical tool for quality control of herbal drugs from L. ferrea.
\end{abstract}

Keywords: Libidibia ferrea, Quality control, Spectrophotometry, Tannins.

\footnotetext{
*Author for correspondence: phtech@uol.com.br
} 


\section{INTRODUCTION}

Libidibia ferrea (Mart. ex Tul.) L. P. Queiroz is a tree that belongs to the Fabaceae family and is presented as basinomium Caesalpinia ferrea Martius. The species is widely known as "jucá" or "pau ferro" and can be found on the "Caatinga" region extending to the northeast and north of Brazil ${ }^{1,2}$. Moreover, the species is used in the north of Brazil for urban arborization and landscape design ${ }^{3}$. The stem bark and pods are the parts of $L$. ferrea most commonly used in popular medicine, and is mainly used as an anti-inflammatory and anti-asthmatic aid. In addition, the literature reports the relationship between the tannins of this species and its several biological properties, these include: antimicrobial, anti-inflammatory and hypoglycemic properties ${ }^{4-9}$. Regarding the chemical composition of $L$. ferrea, the presence of flavonoids, coumarins, steroids and other phenolic compounds have already been reported ${ }^{6,9,10}$.

Notwithstanding the relevance of this species in traditional practices, there are not enough data/parameters of quality to establish specifications for use of this species in folk medicine or as raw material for industrial production of herbal medicines ${ }^{11,12}$.

In this context, the quantification of marker compounds (analytical or active) plays an important role on the evaluation and prediction of the quality of herbal drugs and herbal medicines ${ }^{13}$. What is more, the quantitative determination of tannins becomes a valid strategy for the chemical analysis and initial quality specifications of herbal materials from this species.

Despite the reports of selective techniques for the quantification of tannins, such as high performance liquid chromatography ${ }^{14-16}$, which includes the pods from $L$. ferrea ${ }^{10}$, the procedure is used only to quantify the monomers of tannins (gallic acid, ellagic acid or catechin) due to the complexity, variability and stability of hydrolysable or condensed tannins ${ }^{17-19}$. However, the quantification of tannins by spectrophotometry allows for the estimation of the total content including the polymers (hydrolyzable or condensed derivatives), avoiding the underestimation of the analytical response, a common fact in certain selective methods due to the unavailability of reference standards and/or difficulty of structural elucidation of these macromolecules. Additionally, the spectrophotometric method is still the most used due to its simplicity, low cost and availability in analytical laboratories ${ }^{20,21}$. This approach also ensures the principle of the synergistic effect attributed to medicinal plants, especially for species whose active compounds have not yet been reported, such as L. ferrea ${ }^{22}$.

In order to quantify tannins by UV-spectrophotometry, the colorimetric FolinCiocalteu method shows the reactional stability able to ensure the necessary reproducibility for the validation study required by international guidelines and health authorities ${ }^{23-25}$.

The reaction product from Folin-Ciocalteu is result of unspecific oxidation with polyphenols. Thus, the coloration and intensity observed after reaction does not correspond exclusively with tannins. Therefore, the complexation of tannin is indispensable to attribute specificity to the method. Then, the tannins are removed by filtration or centrifugation after formation of insoluble complexes with macromolecules. After this, the content of tannin is established by the difference between the reaction product of total polyphenols and the reaction product of the fraction of non-adsorbed polyphenols ${ }^{26-29}$.

In spite of reports in the literature, the adoption of spectrophotometric methods for qualitative analysis of plant drugs is highly dependent on the composition of each matrix and critical factors such as reagents, reaction medium and time. Consequently, the performance of analytical methods must be subjected to a series of tests with the purpose of proving their efficiency in the uses that are being proposed and the 
applicability of these in the laboratory routine ${ }^{20,23}$. Thus, the main purpose of this study was to evaluate the analytical critical variables and to validate the FolinCiocalteu method for quantitative determination of total tannins in stem bark and pods of L. ferrea.

\section{MATERIAL AND METHODS}

\section{Herbal Material}

The stem bark and pods of $L$. ferrea were collected in Limoeiro (Pernambuco) and the identification was performed by the Agronomic Institute of Pernambuco (IPA), the registration was deposited under number 88145 . The samples were submitted to drying in a circulating air oven (Luca-82/480, Lucadema ${ }^{\circledR}$ ) at $40{ }^{\circ} \mathrm{C}$, for $96 \mathrm{~h}$, and then ground in a Willey knife mill $\left(\mathrm{Tecnal}^{\circledR}\right)$.

\section{Reagents and Glassware}

Calibrated glassware and analytical grade reagents were used: anhydrous sodium carbonate $\left(\right.$ FMaia $\left.^{\circledR}\right)$, Folin-Ciocalteu (Dinâmica $\left.{ }^{\circledR}\right)$, casein $\left(\right.$ Sigma $\left.^{\circledR}\right)$, skin powder $\left(\right.$ Merck $\left.^{\circledR}\right)$, polyvinylpyrrolidone - PVP $\left(\right.$ Sigma $\left.^{\circledR}\right)$, gallic acid $\left(\operatorname{Vetec}^{\circledR}\right)$, catechin $\left(\right.$ Sigma $\left.^{\circledR}\right)$, and pyrogallol $\left(\right.$ Fluka $\left.^{\circledR}\right)$.

\section{Chromatographic Profile by TLC of Tannins from Stem Bark and Pods of L. Ferrea}

The samples were obtained by reflux, at $10 \%(\mathrm{w} / \mathrm{v})$ with methanol as solvent. Pre-coated TLC silica gel $60 \mathrm{~F}_{254}$ aluminum plates $(10 \mathrm{~cm} \times 10 \mathrm{~cm} ; 250 \mu \mathrm{m}$ thickness; Merck $^{\circledR}$, Germany) were used and the mobile phase constituted of the mixture of ehtyl acetate: formic acid: water (90:5:5, v:v:v). The sample applicator using $100 \mu \mathrm{L}$ syringe (Hamilton ${ }^{\circledR}$, Schweiz) connected to compressed air and winCATS ${ }^{\circledR}$ software (Camag ${ }^{\circledR}$, Switzerland). The plate was developed in a twin trough vertical glass chamber $\left(\mathrm{Camag}^{\circledR}\right)$ with $10 \mathrm{x} 10 \mathrm{~cm}$ dimensions and was used to develop the chromatograms after 1 hour of saturation with the mobile phase. The following were applied on the plate, $10 \mu \mathrm{L}$ of each sample (stem bark or pods) and $5 \mu \mathrm{L}$ of standard solution of gallic acid $(0.5 \mathrm{mg} / \mathrm{mL})$. After development, the plate was dried and the components were visualized by ultraviolet (UV) irradiation at $254 \mathrm{~nm}$ and then derivatized with solution of ferric chloride $1 \%(\mathrm{w} / \mathrm{v})$.

\section{General Procedure for Quantification of Total Tannin Content}

\section{Stock Solution}

About $0.75 \mathrm{~g}$ of the ground herbal material was transferred to a $250 \mathrm{~mL}$ round bottom flask and $150.0 \mathrm{~mL}$ of distilled water was added. The mixture was refluxed in a water bath $\left(\right.$ Lucadema ${ }^{\circledR}$ ) for 30 minutes at $85{ }^{\circ} \mathrm{C}$, cooled to room temperature and then quantitatively transferred to a $250 \mathrm{~mL}$ volumetric flask. After that, the round-bottomed flask was rinsed and the washings collected in the volumetric flask, then diluted to 250 $\mathrm{mL}$ with water, and finally filtered through filter paper, discarding the first $50 \mathrm{~mL}$. The filtrate was the stock solution (SS - $0.002 \mathrm{~g} / \mathrm{mL}$ ). 
Sample Solution for Total Polyphenols

An aliquot of $5.0 \mathrm{~mL}$ of the $\mathbf{S S}$ was taken and diluted with distilled water in a $25 \mathrm{~mL}$ volumetric flask. Then, $2.0 \mathrm{~mL}$ of this solution, $1.0 \mathrm{~mL}$ of Folin-Ciocalteu reagent and $10 \mathrm{~mL}$ of distilled water were transferred to a $25 \mathrm{~mL}$ volumetric flask and the volume was filled with a solution of anhydrous sodium carbonate $\left(\mathrm{Na}_{2} \mathrm{CO}_{3}\right)$ at $29 \%(\mathrm{w} / \mathrm{v})$. After 30 minutes, the absorbance corresponding to total polyphenols was measured at $760 \mathrm{~nm}\left(\mathrm{~A}_{1}\right)$ using distilled water for zero adjustment.

\section{Sample solution for non-adsorbed polyphenols}

An aliquot of $10.0 \mathrm{~mL}$ of the $\mathbf{S S}$ was added to the complexing agent (skin powder, casein or polyvinylpyrrolidone) and subjected to $125 \mathrm{~mL}$ erlenmeyer agitation for 60 minutes. The resulting solution was filtered through filter paper and $5.0 \mathrm{~mL}$ of filtrate diluted with distilled water in a $25 \mathrm{~mL}$ volumetric flask. Then, $2.0 \mathrm{~mL}$ of this solution, $1.0 \mathrm{~mL}$ of Folin-Ciocalteu reagent and $10 \mathrm{~mL}$ of distilled water were transferred to a $25 \mathrm{~mL}$ volumetric flask and the volume was filled with a solution of $\mathrm{Na}_{2} \mathrm{CO}_{3}$ at $29 \%$ (w/v). After 30 minutes, absorbance corresponding to the non-adsorbed polyphenols was measured at $760 \mathrm{~nm}\left(\mathrm{~A}_{2}\right)$ using distilled water for zero adjustment.

\section{Standard Solution}

$50.0 \mathrm{mg}$ of each reference standard (gallic acid, catechin or pyrogallol) were dissolved in $100 \mathrm{~mL}$ of distilled water. Then, $5.0 \mathrm{~mL}$ of the standard solution was transferred to a $100 \mathrm{~mL}$ volumetric flask and the volume filled with the same solvent. Finally, 2.0 $\mathrm{mL}$ of this solution, $1.0 \mathrm{~mL}$ of Folin-Ciocalteu reagent and $10.0 \mathrm{~mL}$ of distilled water were transferred to a $25 \mathrm{~mL}$ volumetric flask and the volume was filled with a solution of $\mathrm{Na}_{2} \mathrm{CO}_{3}$ at $29 \%$ (w/v). After 30 minutes, the absorbance of the standard solution was measured at $760 \mathrm{~nm}\left(\mathrm{~A}_{3}\right)$ using distilled water for zero adjustment.

The total tannin content was calculated as percentage of tannins (dry drug), expressed in $\mathrm{g} \%$ of the standard, according to Equation 1:

$$
T T=\frac{62.5 \times\left(A_{1}-A_{2}\right) \times m_{2}}{A_{3} \times m_{1}}(\text { Eq. 1) }
$$

Where: TT $=$ total tannin content in $\mathrm{g} \%$ of standard; $\mathrm{A}_{1}=$ absorbance of the sample solution for total polyphenols; $\mathrm{A}_{2}=$ absorbance of the sample solution for non-adsorbed polyphenols; $\mathrm{A}_{3}=$ absorbance of standard solution; $\mathrm{m}_{1}=$ mass of the sample used in the test, in grams, considering the determination of water; $\mathrm{m}_{2}=$ mass of the standard, in grams, considering purity.

\section{Evaluation of Operational and Reactive Parameters of the Folin-Ciocalteu Method}

\section{Determination of Wavelength and Reaction Time}

The wavelength for analyses was evaluated for samples and standards by spectrums in the region from 400 to $900 \mathrm{~nm}$, after 30 minutes of addition of the last reagent described in the general procedure for preparation of samples for total polyphenols. The spectral data were used to choose the maximums and for evaluation of the samples dilutions. The reaction time was studied from the reaction kinetics 
(absorbance versus reaction times) for each analyte (samples or standards). The measurements were initiated 5 minutes after the addition of the last reagent $\left(\mathrm{Na}_{2} \mathrm{CO}_{3}\right.$ solution, 29\%, w/v), and repeated at each 5 minutes interval during 60 minutes.

Determination of the Reference Standard

Calibration curves of reference substances (gallic acid, catechin or pyrogallol) were constructed using five concentration levels (1.00 to $8.00 \mu \mathrm{g} / \mathrm{mL})$ for choice of reference standard. The determination was carried out in a spectrophotometer after the execution of the reaction procedures to determine total polyphenols. The results were analyzed by linear regression using the least squares method, and the coefficient of determination $\left(R^{2}\right)$ was calculated. The selection of the reference standard for the methodology was performed according to Bueno $(2012)^{30}$, evaluating the average angular coefficient of three curves and the molar absorptivity of each substance calculated by the equation: $\mathrm{A}=\varepsilon . b . c$, where $\mathrm{A}=$ absorbance (A.U.); $\varepsilon=$ molar absorptivity $(\mathrm{mol} / \mathrm{L}) ; \mathrm{b}=$ optical path of the cell $(\mathrm{cm}) ; \mathrm{c}=$ sample concentration $(\mathrm{g} / 100$ $\mathrm{mL})^{30,31}$.

\section{Evaluation of the Drug:Solvent Ratio}

The samples were prepared using different amounts $(0.50,0.75$ or $1.00 \mathrm{~g})$ of the herbal material (stem bark or pods), following the procedures for obtaining the stock solution and total polpyhenol determination ${ }^{32}$.

\section{Evaluation of the Influence of Folin-Ciocalteu Reagent and $\mathrm{Na}_{2} \mathrm{CO}_{3}$ Solution}

The influence of the reaction conditions on the total tannin content was evaluated through a factorial design $2^{2}$ using Folin-Ciocalteu reagent $\left(1\right.$ and $3 \mathrm{~mL}$ ) and $\mathrm{Na}_{2} \mathrm{CO}_{3}$ solution (10 and $29 \%, \mathrm{w} / \mathrm{v})$ as independent variables). The matrix was added with three central points (Folin $=2 \mathrm{~mL}, \mathrm{Na}_{2} \mathrm{CO}_{3}=15 \%$, w/v), and the experiments were performed in triplicate ${ }^{33}$. The dependent variable evaluated in the study was the total tannin content (TT) expressed in $\mathrm{g} \%$ of reference standards, from the absorbance read after 30 minutes of addition of the last reagent. Statistical analysis of the data was performed by ANOVA and the data were used to calculate response surfaces using the Microsoft Excel $^{\circledR}$ and STATISTICA ${ }^{\circledR} 6.0$ programs (StatSoft, USA).

\section{Evaluation of the Complexing Agent}

In this step, different types (casein, PVP and skin powder) and amounts (100, 150 and $200 \mathrm{mg}$ ) of complexing agents were evaluated to verify the influence on total tannin content ${ }^{28,34}$. The total tannin content was calculated and the results expressed as mean, standard deviation and relative standard deviation (RSD\%).

\section{Validation of Analytical Methods}

The method was validated according to the parameters recommended by the regulatory agencies: National Agency of Sanitary Surveillance (Anvisa) ${ }^{23}$ and International Conference Harmonization (ICH) ${ }^{24}$, using as parameters: linearity, specificity, limits of detection and quantification, accuracy and robustness. The statistical reliability of the results was established from the relative standard deviation (RSD\%). Some of the results were treated by analysis of variance (ANOVA) OneWay or Two-Way and $t$-student test, in order to verify significant differences between means or variances resulting from the assays. 


\section{Linearity}

The stem bark or pod samples were prepared as described above, and after appropriate dilutions, had a concentration range of $16.0-48.0 \mu \mathrm{g} / \mathrm{mL}$ for stem bark and 8.0-40.0 $\mu \mathrm{g} / \mathrm{mL}$ for pods. In addition, standard solutions were obtained, with concentrations of between 1.0 and $8.0 \mu \mathrm{g} / \mathrm{mL}$. The results were analyzed by linear regression using the least squares method to calculate the coefficient of determination $\left(R^{2}\right)$ and other parameters of the mathematical model.

\section{Specificity}

Specificity was evaluated by the method of addition of the standard, where the solutions used for the linearity test were contaminated with defined amounts of reference standards ( $25 \mathrm{mg}$ of pyrogallol, $50 \mathrm{mg}$ of gallic acid or catechin) to elaborate the specificity curves. Finally, a comparison was made between the slopes obtained for the linearity curves and the specificity of the method ${ }^{30,35}$.

\section{Limits of Detection and Quantification}

The limits of detection (LOD) and quantification (LOQ) were estimated using the equations below available in Specific Resolution (RE 899) ${ }^{23}$ :

$$
L O D=\frac{S \times 3}{I} L O Q=\frac{S \times 10}{I}
$$

Where, $S$ is the standard deviation of the intercept with the y-axis of at least 3 calibration curves constructed for the substance of interest and $I$ is the mean slope of the 3 authentic calibration curves. All results were expressed in $\mu \mathrm{g} / \mathrm{mL}$.

\section{Precision}

The precision was evaluated at two levels: repeatability, with analysis of 6 samples at the same concentration (100\%), on the same day and by the same operator; and, intermediate precision, by analyzing 3 samples at the same concentration (100\%), by two analysts and on two different days. The results were expressed as $\mathrm{g} \%$ of standard.

\section{Accuracy}

Accuracy was evaluated by recovery assay, through which extractive solution samples from stem barks or pods were fortified with the standard at three concentration levels. The percent recovery was calculated from the ratio between the experimentally determined mean concentrations and the expected theoretical concentrations for the fortified solution. Extracts were used in concentrations of $16.0 \mu \mathrm{g} / \mathrm{mL}$ of stem barks and $32.0 \mu \mathrm{g} / \mathrm{mL}$ of pods, and to these were added three quantities of standard (25.0, 50.0 and $75.0 \mu \mathrm{g}$ ), then the usual procedure was performed to determine the absorbance.

\section{Robustness}

To evaluate the robustness, the parameters of stability of the reaction product to the luminosity (absence or presence), stability of the extractive solutions $(0 \mathrm{~h}$ and $6 \mathrm{~h})$ and different equipment for the reading of the samples were considered (Evolution 60S, Thermo Scientific ${ }^{\circledR}$ and AJX 1900, Micronal ${ }^{\circledR}$ ). 


\section{RESULTS}

The chromatographic analysis by TLC of the samples evidenced the presence of hydrolyzable tannins from stem bark and pods of $L$. ferrea (Figure 1). In addition to the typical bands for hydrolyzable tannins (gray bluish), both samples showed a band with the same color and Rf value (0.85) than the spot observed for the standard of gallic acid.

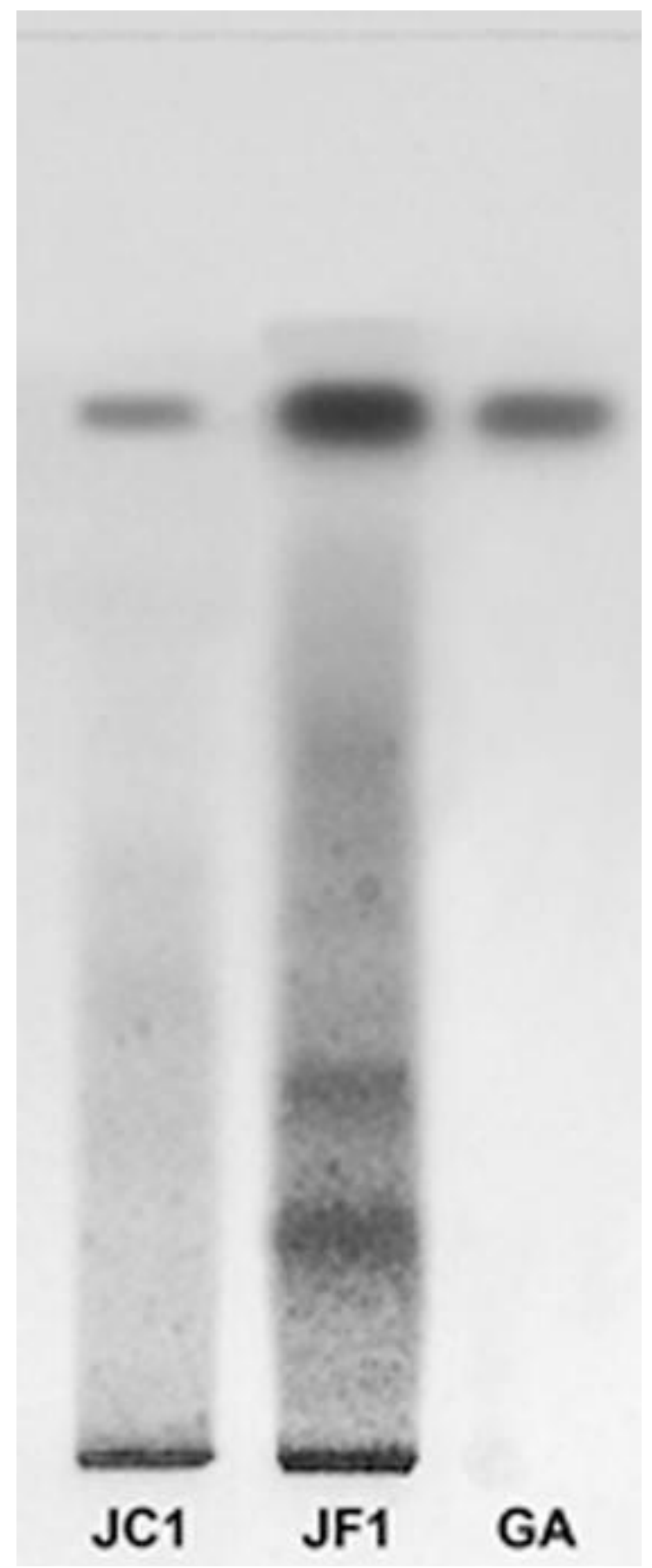

Figure 1. Chromatogram obtained by TLC indicating the presence of gallic acid (GA) in the samples of stem bark (JC1) and pods (JF1) L. ferrea after derivatization with ferric chloride (1\% ethanol). 


\section{Evaluation of the Analytical Parameters of Folin-Ciocalteu Method}

In order to study the most appropriate reference standard, calibration curves were constructed for each chemical standard (gallic acid, catechin and pyrogallol) and the coefficients of molar absorptivity $(\varepsilon)$ and angular coefficients $(\alpha)$ were calculated. The results are presented in Table 1 and show a similar behavior for gallic acid and catechin, while the analytical procedure was more sensitive to pyrogallol showing higher values for both coefficients.

Table 1. Results of linearity, limits of detection (LOD) and quantification (LOQ) and molar absorptivity, from calibrations curves for samples (stem bark and pods) and standards (pyrogallol, catechin and gallic acid).

\begin{tabular}{|c|c|c|c|c|c|}
\hline \multirow[b]{2}{*}{ Parameters } & \multicolumn{2}{|c|}{ Herbal drugs } & \multicolumn{3}{|c|}{ Standards } \\
\hline & Stem bark & Pods & Pyrogallol & Catechin & Gallic acid \\
\hline Concentration $(\mu \mathrm{g} / \mathrm{mL})$ & $16.0-48.0$ & $8.0-40.0$ & $1.0-5.0$ & $2.0-7.0$ & $2.0-8.0$ \\
\hline Slope (a) & 0.0134 & 0.0204 & 154.0 & 101.94 & 102.52 \\
\hline Interception (b) & 0.1115 & 0.0772 & -0.0060 & 0.0401 & 0.0072 \\
\hline$R^{2}$ & 0.9994 & 0.9988 & 0.9996 & 0.9994 & 0.9999 \\
\hline $\mathrm{LOD}(\mu \mathrm{g} / \mathrm{mL})$ & 1.5302 & 1.0425 & - & - & - \\
\hline LOQ $(\mu \mathrm{g} / \mathrm{mL})$ & 5.1007 & 3.4751 & - & - & - \\
\hline Molar absortivity $(\varepsilon)$ & - & - & 1462.2 & 1113.3 & 1045.0 \\
\hline
\end{tabular}

All the scanning spectrums obtained for extractive solutions and standards showed a similar maximum at $\lambda=760 \mathrm{~nm}$, after the Folin-Ciocalteu reaction. The reaction kinetics at this wavelength showed that the absorbance increased during the initial 30 minutes, then stabilization was achieved and was followed by a gradual decrease in the absorbance intensities. In regard to the amount of herbal material, $0.50 \mathrm{~g}$ of drug material was enough to provide the highest experimental responses, independent of the part of plant evaluated (stem bark or pods). The data were calculated as total polyphenols content and expressed in $\mathrm{g} \%$ of each of the standards (Fig. 2A and 2B). 


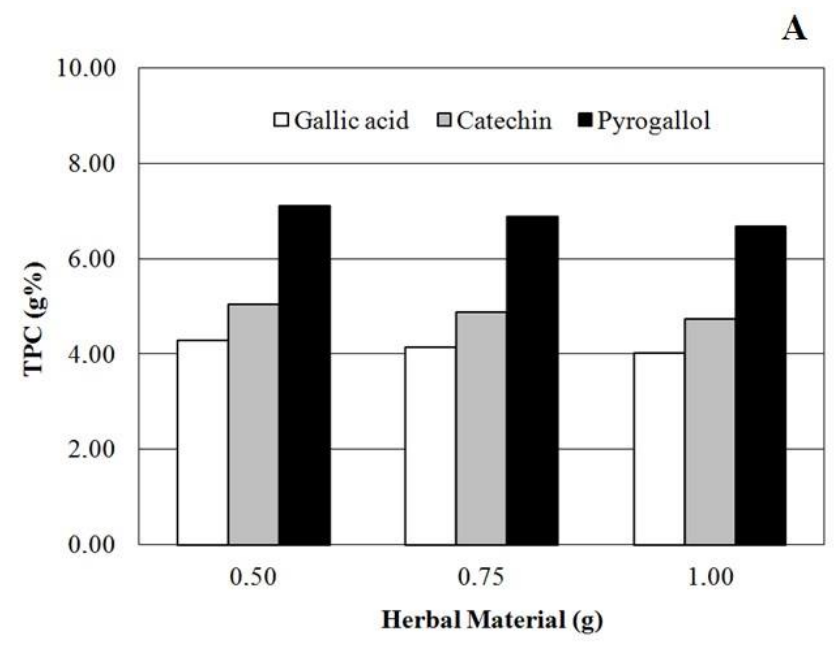

B

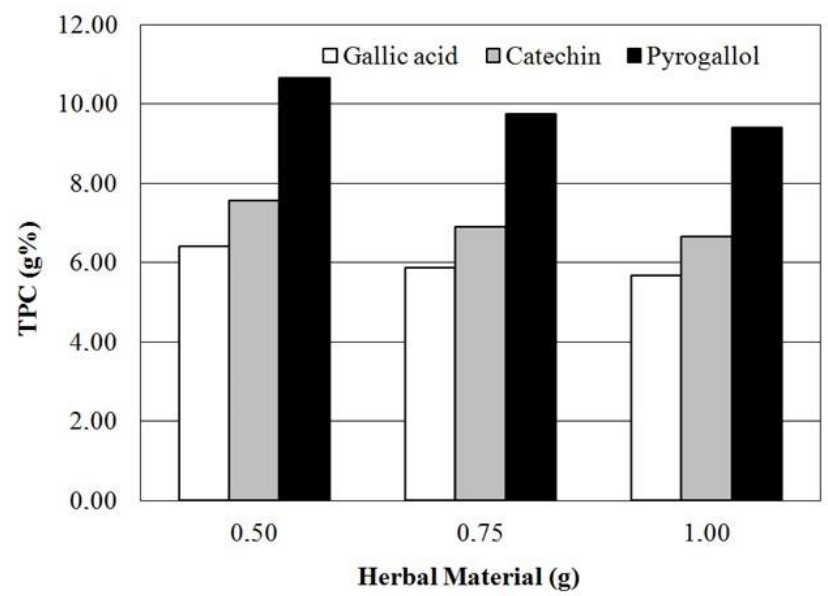

Figure 2. Effect of drug amount on total polyphenol content (TPC, g\%) of stem bark (A) and pods (B) from $L$. ferrea.

Regarding the influence of the complexing agent, Fig. 3 shows the performance of each macromolecule (casein, PVP or skin powder) as precipitants of tannin in stem bark (A) and pods (B) from L. ferrea. Regarding the analysis of tannin from stem bark, the complex profiles observed for casein and PVP showed a similar behavior, improving the analytical response when the amount of macromolecules was increased (Fig. 3A). On the other hand, the use of skin powder as an agent provides higher interaction with tannin and the maximum could be observed at a lower concentration of the agent $(100 \mathrm{mg})$. Casein and PVP also achieved maximum interaction, but this occurs only at a higher concentration $(200 \mathrm{mg})$. Thus, total tannin in stem bark was calculated and was found to range from 10 to $12 \mathrm{~g} \%$.

Concerning the evaluation of tannin content in pods from $L$. ferrea, the use of PVP or skin powder provides the maximum yield from the lowest concentration (Fig. 3B). However, the content was lower than that observed for stem bark, at about $8 \mathrm{~g} \%$. Additionally, the casein showed less ability to interact with the tannin than the other macromolecules. 
A
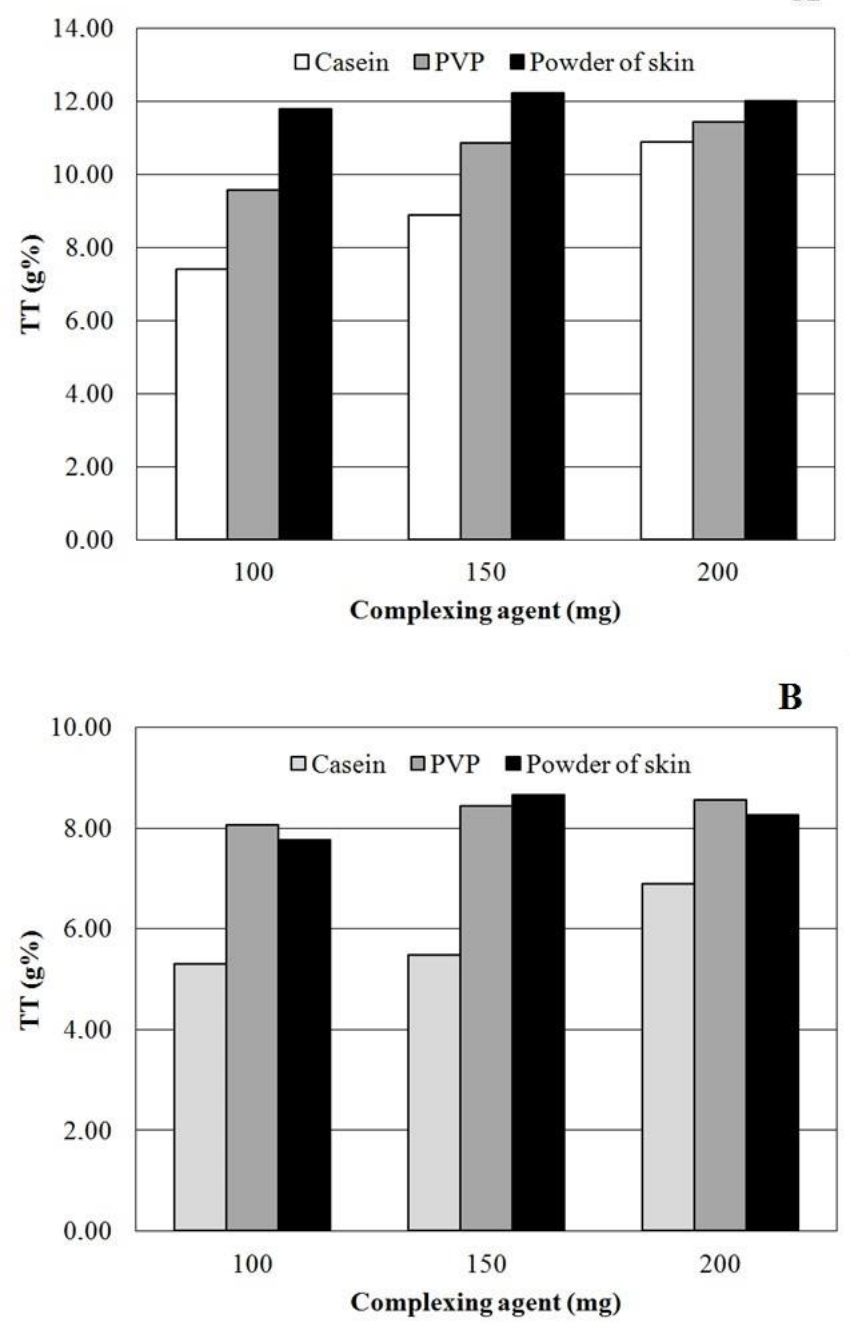

Figure 3. The effect of complex agent on the total tannin (TT, g\%) of stem bark (A) and pods (B) from L. ferrea.

The influences of the Folin-Ciocalteu reagent and the $\mathrm{Na}_{2} \mathrm{CO}_{3}$ solution on the response of the analytical method were studied by response surface methodology. The mathematical models used to generate the surfaces were evaluated by ANOVA and the data are presented in Table 2. According to the results, the proportion of the FolinCiocalteu reagent caused a negative effect on the analytical response reducing the total tannins content. While the concentration of $\mathrm{Na}_{2} \mathrm{CO}_{3}$ presented a positive influence, favoring the responses in all the conditions studied. In this way, the maximization of the responses could be observed when using lower Folin-Ciocalteu reagent volume and higher $\mathrm{Na}_{2} \mathrm{CO}_{3}$ concentration (Fig. 4). 
Table 2. Statistical analysis of the experimental design.

\begin{tabular}{|c|c|c|c|c|c|c|c|c|c|c|c|c|}
\hline \multirow[b]{3}{*}{ Factors } & \multicolumn{6}{|c|}{ Stem bark } & \multicolumn{6}{|c|}{ Pods } \\
\hline & \multicolumn{2}{|c|}{ Cathechin } & \multicolumn{2}{|c|}{ Gallic acid } & \multicolumn{2}{|c|}{ Pyrogallol } & \multicolumn{2}{|c|}{ Cathechin } & \multicolumn{2}{|c|}{ Gallic acid } & \multicolumn{2}{|c|}{ Pyrogallol } \\
\hline & $F$-test & $t$-test & $F$-test & $t$-test & $F$-test & $t$-test & $F$-test & $t$-test & $F$-test & $t$-test & $F$-test & $t$-test \\
\hline Folin (Linear) & $59.50 *$ & $-7.71 *$ & $46.91 *$ & $-6.85 *$ & $23.21 *$ & $-4.82 *$ & $54.58^{*}$ & $-7.39 *$ & $42.99 *$ & $-6.56 *$ & $22.12 *$ & $-4.70 *$ \\
\hline Folin (Quadratic) & 1.63 & 1.28 & $7.30 *$ & $2.70 *$ & $15.42 *$ & $3.93 *$ & $19.34 *$ & $4.40 *$ & 0.29 & 0.54 & 0.06 & 0.25 \\
\hline $\mathrm{Na}_{2} \mathrm{CO}_{3}$ (Linear) & $49.22 *$ & $7.01 *$ & $112.98^{*}$ & $10.63^{*}$ & $48.46^{*}$ & $6.96 *$ & $45.61^{*}$ & $6.75^{*}$ & $104.73 *$ & $10.23^{*}$ & $47.13^{*}$ & $6.87 *$ \\
\hline $\begin{array}{l}\text { Interaction } \\
\left(\text { Folin } x \mathrm{Na}_{2} \mathrm{CO}_{3}\right)\end{array}$ & $6.27 *$ & -2.50 & $0.53 *$ & 0.73 & 0.21 & -0.46 & $6.04 *$ & $-2.46^{*}$ & $0.42 *$ & 0.65 & 0.27 & -0.52 \\
\hline LOF & 0.21 & & 0.22 & & 1.67 & & 0.20 & & 0.21 & & 1.61 & \\
\hline
\end{tabular}



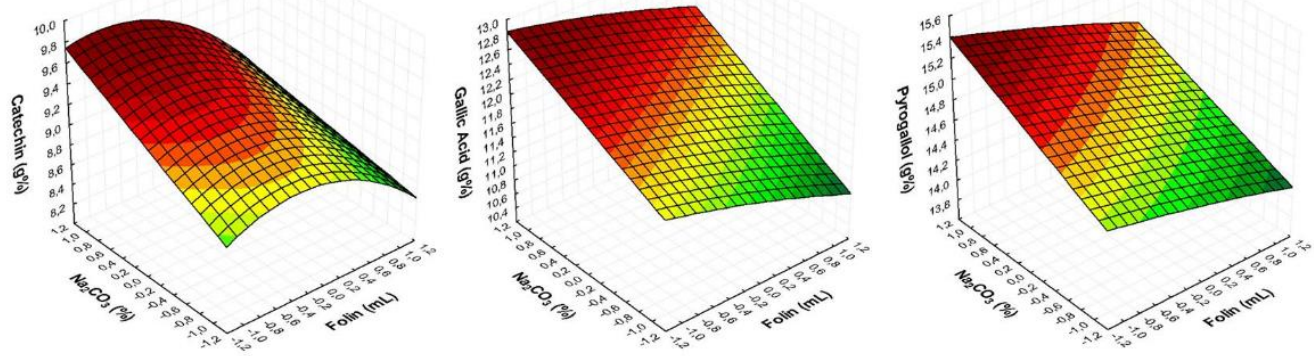

L. ferrea- Pods
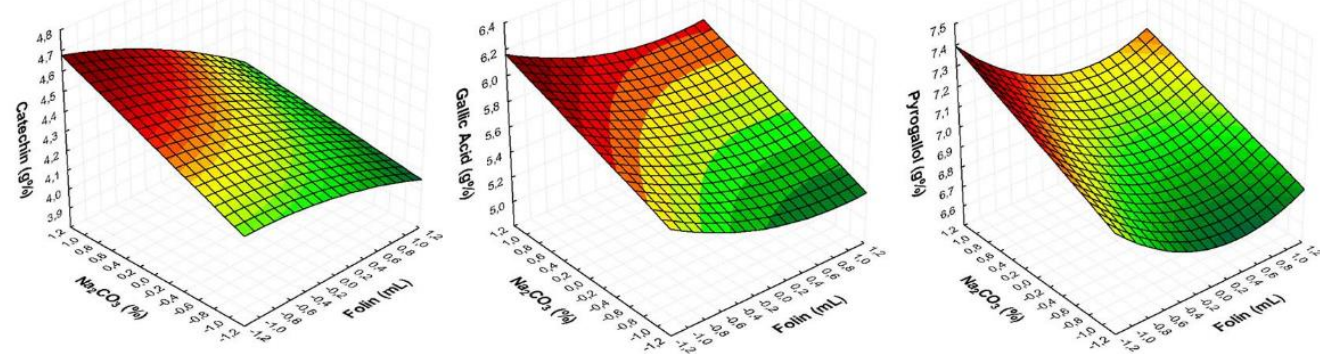

Figure 4. Response Surfaces of stem bark and pods, for evaluation of Folin-Ciocalteu reagent and sodium carbonate on the levels of tannins.

\section{Validation}

\section{Curves of Linearity, Limits of Detection (LOD) and Quantification (LOQ)}

To evaluate linearity curves of the samples, we adopted the absorbance data resulting from the difference between total polyphenols and non-adsorbed fraction. Stem bark and pods were evaluated in the concentration ranges presented in Table 1, and the curves showed determination coefficients $\left(R^{2}\right)$ equal to 0.9999 and 0.9988 for stem barks and pods, respectively. This data confirm the linear dependence of analytical response and the analyte concentration for both samples under study. The limits of detection (LOD) and quantification (LOQ) were calculated through the calibration curves obtained for the solutions of the standards.

\section{Specificity}

Figure 5 presents the average linearity curves (total polyphenols solution for stem bark and pods) and the mean specificity curves obtained with the addition of reference substances. The statistical analysis of the mathematical models obtained by linear regression indicates that there was no significant difference between the angular coefficients of curves (Table 2). Thus, the response behavior of sample curves (stem bark and pods) can be explained satisfactorily by any of the three reference standards evaluated. 


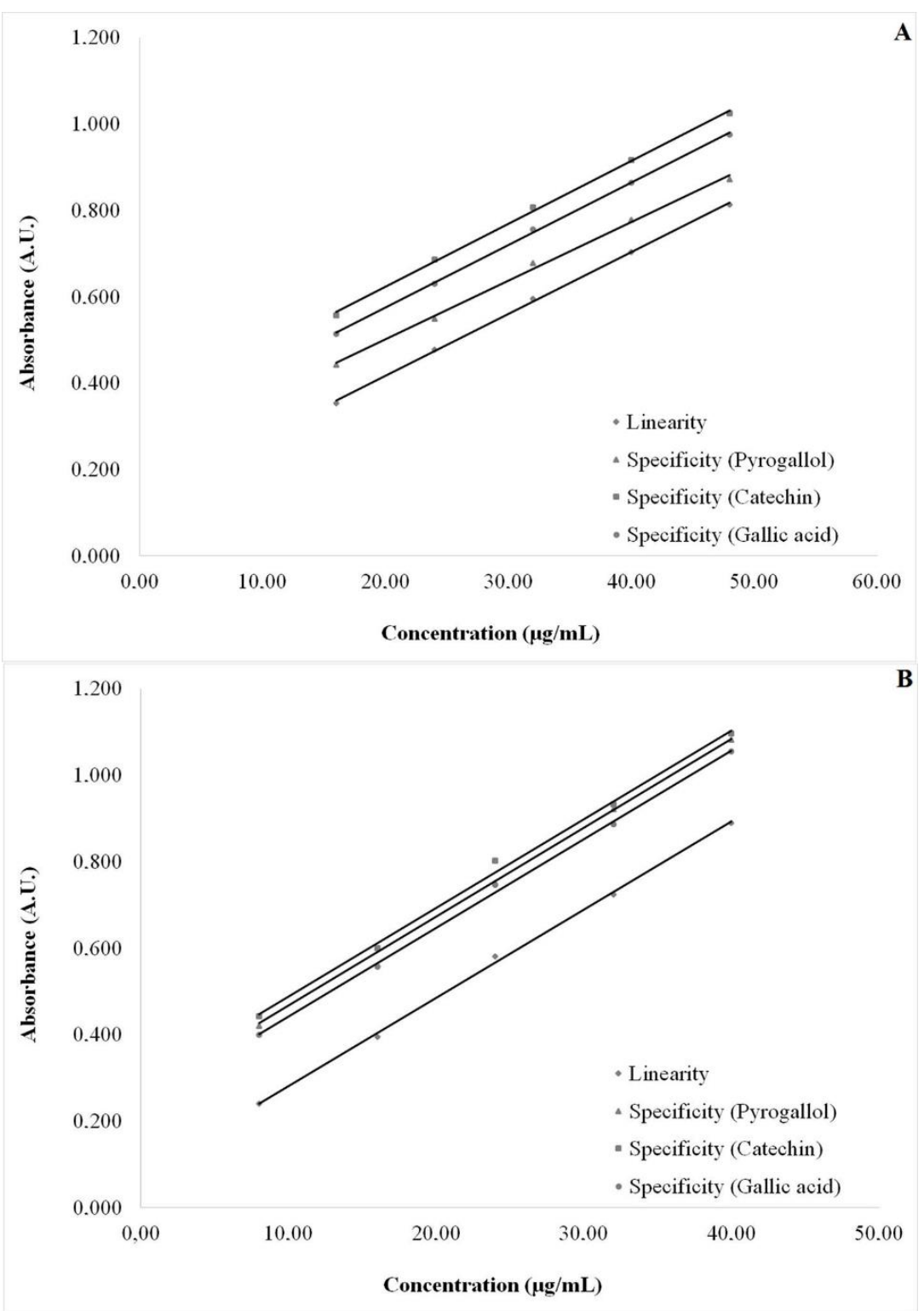

Figure 5. Curves of linearity and specificity from stem bark (A) and pods (B) of L. ferrea.

Precision, Accuracy and Robustness

The precision data of the methods are summarized in Table 3. In regard to the precision tests, the results showed a maximum relative standard deviation of $1.28 \%$ for repeatability and $4.9 \%$ for intermediate precision. In the accuracy test, the stem bark presented recovery rates in the range of $96.84 \%$ to $103.13 \%$, with a mean of $100.73 \%$ (2.14\%); while for pods the recovery was between $104.12 \%$ and $109.13 \%$, with an average of $106.07 \%(2.53 \%)$. Finally, in the robustness test (Table 4), RSD\% values higher than $5 \%$ were not obtained for the means calculated in the different experimental conditions. 
Table 3. Results of precision (repeatability and intermediate precision) expressed by total tannin content (TT).

\begin{tabular}{|c|c|c|c|c|}
\hline Part of plant & Parameters & \multicolumn{2}{|c|}{ TT $(\mathrm{g} \%)($ mean \pm SD; RSD\% $)$} & $F_{\text {calc }}$ \\
\hline \multirow{4}{*}{ Stem bark } & Repeatability & \multicolumn{2}{|c|}{$12.12 \pm 0.110(0.91)$} & - \\
\hline & Intermediate precision & Day 1 & Day 2 & - \\
\hline & Analyst 1 & $12.45 \pm 0.071(0.57)$ & $11.31 \pm 0.243(2.15)$ & 0.38 \\
\hline & Analyst 2 & $12.49 \pm 0.082(0.66)$ & $11.38 \pm 0.094(0.83)$ & 0.38 \\
\hline \multirow{4}{*}{ Pods } & Repeatability & \multicolumn{2}{|c|}{$13.90 \pm 0.178(1.28)$} & - \\
\hline & Intermediate precision & Day 1 & Day 2 & - \\
\hline & Analyst 1 & $13.81 \pm 0.136(0.98)$ & $14.16 \pm 0.081(0.58)$ & 0.51 \\
\hline & Analyst 2 & $13.91 \pm 0.080(0.58)$ & $14.23 \pm 0.081(0.57)$ & 0.02 \\
\hline
\end{tabular}

g\% of pyrogallol; SD: standard deviation; RSD: relative standard deviation.

Table 4. Results of robustness expressed by total tannin content (TT).

\begin{tabular}{|c|c|c|c|}
\hline Part of plant & Parameters & Variables & $\begin{array}{c}\text { TT }(\mathrm{g} \%) \\
\text { mean } \pm \text { SD, }(\text { RSD\% })\end{array}$ \\
\hline \multirow{9}{*}{ Stem bark } & & Absence & $12.18 \pm 0.200(1.64)$ \\
\hline & Luminosity & & \\
\hline & & Presence & $12.67 \pm 0.070(0.55)$ \\
\hline & & $0 \mathrm{~h}$ & $12.39 \pm 0.095(0.77)$ \\
\hline & Stability of extractive solution & & \\
\hline & & $6 \mathrm{~h}$ & $12.07 \pm 0.199(1.65)$ \\
\hline & & Evolution 60S, Thermo Scientific ${ }^{\circledR}$ & $12.39 \pm 0.094(0.76)$ \\
\hline & Equipment & & \\
\hline & & AJX 1900, Micronal $^{\circledR}$ & $12.67 \pm 0.070(0.55)$ \\
\hline \multirow{8}{*}{ Pods } & & Absence & $14.06 \pm 0.178(1.26)$ \\
\hline & Luminosity & Prosanco & $1455+0156(108)$ \\
\hline & & 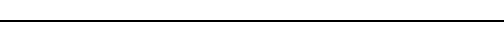 & (1) \\
\hline & & $0 \mathrm{~h}$ & $14.59 \pm 0.148(1.02)$ \\
\hline & Stability of extractive solution & & \\
\hline & & $6 \mathrm{~h}$ & $13.95 \pm 0.027(0.19)$ \\
\hline & & Evolution 60S, Thermo Scientific ${ }^{\circledR}$ & $13.55 \pm 0.047(0.34)$ \\
\hline & Equipment & AJX 1900, Micronal $^{\circledR}$ & $13.64 \pm 0.134(0.98)$ \\
\hline
\end{tabular}

$\mathrm{g} \%$ of pyrogallol; SD: standard deviation; RSD: relative standard deviation. 


\section{DISCUSSION}

There are several reports in the literature about certain species of the Fabaceae (Leguminosae) family being a source of polyphenols, these include Amburana cearensis (Allemao) A.C. Sm. ${ }^{36}$, Hymenaea stigonocarpa Mart. ex. Hayne ${ }^{37}$, Anadenanthera falcata (Benth.) Speg., and Caesalpinia bracteosa Tul. ${ }^{38}$. When considering the determination of the tannin content described for the species, it is evident that reliable analytical methodologies are fundamental in the evaluation and quantification of the variations in metabolic content due to biological variability and/or their interaction with environmental factors.

In this aspect, prior to the adoption of analytical procedures in new plant matrices, the suitability of the technique must be evaluated for the identification and minimization of possible interferences from different sources, such as the matrix itself or analytical limitations. Thus, the evaluation of variables (dilutions, reagents, time) and the different parts of the plant studied (bark, leaves, pods) are minimum prerequisites for the procedure to be able to detect inter- and intra-individual variations ${ }^{39}$.

Considering that the spectrophotometric technique presents limitations in the selectivity and specificity, the confirmation of the presence of compounds of interest is fundamental for the establishment of the marker(s). One of the most widely used techniques for establishing chemical profiles of the metabolites present in plant species is thin layer chromatography (TLC). It is notable for its simplicity, low cost and speed, and it is worth noting the ease in which it can qualitatively detect the presence of compounds with the aid of reference standards ${ }^{40}$. To enable a more efficient separation process, the technological advances in the area of chromatography have led to the development of equipment that performs the application in a partially or totally automated way, ensuring volume reproducibility and homogeneity in this application $^{41,42}$.

The TLC analysis of samples revealed that stem bark and pods from $L$. ferrea presented a band with same coloration and displacement as that observed for the standard solution of gallic acid. However, on evaluation of pods, the band corresponding to the pattern presented a higher intensity in comparison with stem bark, indicating a higher concentration. In addition, other bands detected for pods (Rf value: 0.16 ; 0.25 ) suggest the presence of derivatives of hydrolyzable tannin (gallic type). The results obtained corroborate with the literature making it possible to prove the presence of hydrolyzable tannins on the stem bark and pods from L. ferrea ${ }^{9,10}$.

The Folin-Ciocalteu method is described for different plant species in official codes, which includes the Brazilian ${ }^{43}$ and British Pharmacopoeia ${ }^{44}$ (2014). However, because of the differences related to the specificities of each herbal matrix, the evaluation of reactional and operational parameters should be considered an important step before validation of the methodology, which will ensure the reliability and reproducibility necessary for the specific quantitative evaluation of this herbal drug ${ }^{28,30,39}$.

In regard to the Folin-Ciocalteu reaction, the presence of hydroxyl groups in the phenolic compounds is a determinant for the oxidation reactions and formation of the reaction product responsible for the coloration proportional to the concentration of the metabolite ${ }^{30,39,45}$. In addition, the reaction depends on the amount of hydroxyls that are present in the aromatic rings of the polyphenols. This effect can be observed when different molecules are analyzed as markers, and thus an increase in the molar absorptivity value is shown in the following order: pyrogallol > catechin > gallic $\operatorname{acid}^{30,31,45,46}$. In this sense, the selection of the reference standard was based on the analytical responses of the different patterns to the Folin-Ciocalteu reaction and their respective molar absorption coefficients. According to the results presented in Table 1, pyrogallol had a higher coefficient of molar absorptivity $(\varepsilon=1462.2)$, a characteristic 
that demonstrates greater sensitivity of this compound to the Folin-Ciocalteu method when compared with gallic acid and catechin.

The interaction between tannin and macromolecules is not a simple analytical step and it depends on several factors such as: temperature; $\mathrm{pH}$; [tannin]:[macromolecule]; the molecular weight; solubility and the number of phenolic hydroxyl groups of the $\operatorname{tannin}^{12,27,28}$. Thus, the choice of the reference substance and the wavelength play an important role in the specificity and/or selectivity of the instrumental technique. The bathochromic shift promoted by the Folin-Ciocalteu reagent resulting from the oxyreduction reactions may present $\lambda_{\max }$ deviation capable of compromising the experimental responses by underestimating the quantitative data. This situation can become more complex due to the structural diversity of polyphenols. In this study, the comparative evaluation of the scanning spectrum $(500-900 \mathrm{~nm})$ obtained for the reference substances (pyrogallol, catechin and gallic acid), and for the studied herbal matrices (stem bark and pods), indicated maximum absorbance at the same wavelength $\left(\lambda_{\max }=760 \mathrm{~nm}\right)$. In addition, previous studies for optimization of this method in several species ${ }^{21,30,39,45}$, reported that pyrogallol was used as reference substance and $\lambda_{\max }$ of $760 \mathrm{~nm}$ was presented.

In relation to the amount of drug, the statistical analysis confirmed the hypothesis of a significant difference between the levels obtained for the different amounts evaluated $(\alpha=0.05)$, and the amount of $0.5 \mathrm{~g}$ of drug material from the both herbal parts (bark and pods) showed the maximum extraction calculated as total polyphenol content.

Regarding the factorial design, the data were used to generate second-order models for the calculated tannins expressed in each chemical marker. The coefficients of each significant term and respective statistical analysis are summarized in Table 2. The influences of each independent variable (Folin-Ciocalteu reagent and $\mathrm{Na}_{2} \mathrm{CO}_{3}$ solution) were significant for both factors, stem bark and for pods. Due to the lack-offit (LOF) test not being significant, the experimental variations could be attributed only to a randomized error. Thus, the fitted models provide an adequate approximation of the true values and no violations of the model assumptions occurred ${ }^{13}$.

The statistical data of the coefficients showed an importance in the linear terms of variables concentration of $\mathrm{Na}_{2} \mathrm{CO}_{3}$ and, mainly, Folin-Ciocalteu reagent. In this way, the conditions elected to use for obtaining higher response of total tannins content were $1 \mathrm{~mL}$ of Folin-Ciocalteu and solution of $\mathrm{Na}_{2} \mathrm{CO}_{3}$ at $29 \%$,

According to the analysis of validation, the calibration curves showed linear behaviors for the analyte in both matrices (stem bark and pods) and the determination coefficients $\left(R^{2}\right)$ in the concentration ranges were higher than 0.99 , demonstrating the appropriate sensitivity of the methodology. In addition, the linear regression analysis showed random distribution of residues ${ }^{33,47}$.

Due to the complexity of the herbal matrices and the impossibility of obtaining the same samples free of interfering substances to the analytical reagents, the assay of specificity is performed by fortifying the samples known concentration of reference solution in order to obtain new calibration curves of total polyphenols. Thus, the constant shifting of the new curves should be proportional to the standard contribution, observed by the parallel behavior (similar slopes), the specificity of which is acceptable ${ }^{30,39}$. In this study, the specificity of the analytical methodology was verified for both herbal matrices and proved for the three standards.

The analysis of precision showed relative standard deviations lower than $5 \%$, as recommended by the national legislation ${ }^{23}$. The spectrophotometric procedure was precise at the two levels: repeatability and intermediate precision; for both herbal matrices (stem bark and pods). In addition, no statistical difference was observed among the data. This test is one of the most important, since it can indicate the effect of the variations that can occur in the laboratory, such as differences between analysts and days, assuring the reproducibility of the methodology. 
In regard to the recovery assay, the analytical procedure showed performance within the limits recommended by the literature, for both herbal matrices. Thus, the instrumental responses after fortification with known amounts of the standard solutions (from 80 to $120 \%$ ) could be attributed to the concentration of analytes ${ }^{48}$.

The measure of robustness is critical to understand the interference of variations from seemingly unimportant procedures such as exposure to day/natural light; the stability of the reaction products (oxidation-reduction of the polyphenols by the FolinCiocalteu reagent); stability of the extractive solutions; and/or, the use of equipment from a different manufacturer.

Thus, the robustness can be defined as the ability of the analytical method to withstand small variations from deliberate or random modifications in the standard analytical procedures, complementing the method reliability and availability. The spectrophotometric method for quantification of tannins from the L. ferrea matrices showed variability lower than $5 \%$ as required (RSD $<1.65 \%$ and RSD $<1.26 \%$ for stem bark and pods, respectively). The overall robustness denotes the method stability in the routine analysis of both herbal matrices.

\section{CONCLUSION}

This work evaluates the performance of the Folin-Ciocalteu method assay for the quantification of tannins in herbal matrices from $L$. ferrea. The procedure was optimized and the validation was carried out in accordance to the parameters required by the literature and presented linearity, selectivity/specificity, precision, accuracy and robustness. Thus, the experimental data allowed us to conclude that standardized conditions ensure the reproducibility and reliability necessary for the use of this simple methodology in the quantitative determination of tannins from stem bark and pods Libidibia ferrea.

\section{ACKNOWLEDGEMENTS}

This work was supported by the CNPq (308386/2015-9), FACEPE (IBPG-08644.04/13; APQ-0493-4.03/14) and ANVISA/MS (TC03/2010).

\section{REFERENCES}

1-Cavalheiro MG, Farias DV, Fernandes GS, Nunes EP, Cavalcanti FS, Vasconcelos I.M, Melo VMM, Carvalho AFU. Atividades biológicas e enzimáticas do extrato aquoso de sementes de Caesalpinia ferrea Mart., Leguminosae. Rev Bras Farmacog. 2009; 19:586-591.

2-Borges LA, Souza LGR, Guerra M, Machado IC, Lewis GP, Lopes AV. Reproductive isolation between diploid and tetraploid cytotypes of Libidibia ferrea (= Caesalpinia ferrea) (Leguminosae): ecological and taxonomic implications. Plant Sys Evol. 2012;298:1371-1381.

3-Lima JD, Silva BMS, Moraes WS, Dantas VAV, Almeida CC. Efeitos da luminosidade no crescimento de mudas de Caesalpinia ferrea Mart. ex Tul. (Leguminosae, Caesalpinoideae). Acta Amazon. 2008;38:5-10.

4-Sampaio FC, Pereira M do S, Dias CS, Costa VC, Conde NC, Buzalaf MA. In vitro antimicrobial activity of Caesalpinia ferrea Martius pods against oral pathogens. $J$ Ethnopharmacol. 2009;124:289-294.

5-Oliveira AF, Batista JS, Paiva ES, Silva AE, Farias YJMD, Damasceno CAR, Brito PD, Queiroz SAC, Rodrigues CMF, Freitas CIA. Avaliação da atividade cicatrizante 
do jucá (Caesalpinia ferrea Mart. ex Tul. var. ferrea) em lesões cutâneas de caprinos. Rev Bras Pl Med. 2010;12:302-310.

6-Vasconcelos CFB, Maranhão HML, Batista TM, Carneiro EM, Ferreira F, Costa J, Soares LA, Sá MD, Souza TP, Wanderley AG. Hypoglycemic activity and molecular mechanisms of Caesalpinia ferrea Martius bark extract on streptozotocin-induced diabetes in Wistar rats. J Ethnopharmacol. 2011;137:1533-1541.

7-Lima SMA, Araújo LC, Sitônio MM, Freitas ACC, Moura SL, Correia MT, Malta DJN, Gonçalves-Silva T. Anti-inflammatory and analgesic potential of Caesalpinia ferrea. Rev Bras Farmacogn. 2012;22:169-175.

8-Pereira LP, da Silva RO, Bringel PH, da Silva KE, Assreuy AM, Pereira MG. Polysaccharide fractions of Caesalpinia ferrea pods: Potential anti-inflamatory usage. J Ethnopharmacol. 2012;139:642-648.

9-Araújo AA, Soares LAL, Ferreira MRA, de Souza Neto MA, da Silva GR, de Araújo RFJr., Guerra GCB, De Melo MCN. Quantification of polyphenols and evaluation of antimicrobial, analgesic and anti-inflammatory activities of aqueous and acetone-water extracts of Libidibia ferrea, Parapiptadenia rigida and Psidium guajava. J Ethnopharmacol. 2014;156:88-96.

10-Ferreira MRA, Fernandes MTM, Viturino WA, Bezerra ICF, De Souza TP, Pimentel MF, Soares LAL. Chromatographic and spectrophotometric analysis of phenolic compounds from fruits of Libidibia ferrea Martius. Pharmacogn Mag. 2016;12:285-291.

11-Soares LAL, Ferreira MRA. Standardization and Quality Control of Herbal Medicines. In. Freitas LAP, Teixeira CCC, Zamarioli CM(Ed.). Recent Developments in Phytomedicine Technology. New York: Nova Science Publishers; 2017. p. 243278.

12-Soares LAL, Maia A, Oliveira AL, Petrovick PR, González Ortega G. Avaliação de Complexos Formados por Catequina e Macromoléculas. Lat Am J Pharm. 2006;25:10-16.

13-Fernandes AJD, Ferreira MRA, Randau KP, Soares LAL. Total flavonoids content in the raw material and aqueous extractives from Bauhinia monandra Kurz (Caesalpiniaceae). The Scientific World Journal. 2012;2012:1-7.

14-Møller C, Hansen SH, Cornett C. Characterization of tannin-containing herbal drugs by HPLC. Phytochem. Anal. 2009;20:231-239.

15-He Y, Wu Q, Hansen SH, Cornett C, Møller C, Lai P. Differentiation of tannincontaining herbal drugs by HPLC fingerprints. Pharmazie. 2013;68:155-159.

16-Dhanani T, Shah S, Kumar S. A validated High-Performance Liquid Chromatography method for determination of tannin-related marker constituents gallic acid, corilagin, chebulagic acid, ellagic acid and chebulinic acid in four Terminalia species from India. J Chromatogr Sci. 2015;53:625-632.

17-Sticher O. Phenolische Verbindugen: Gerbstoff. In. Sticher O, Heilmann J, Zündorf I. (Ed.). Hänsel/Sticher - Pharmakognosie-Phytophamazie. 10. Auf. Stuttgart: WVG; 2015. p. 810-822.

18-Smeriglio A, Barreca D, Belloco E, Trombetta D. Proanthocyanidins and hydrolysable tannins: occurrence, dietary intake and pharmacological effects. Brit $J$ Pharmacol. 2017;174:1244-1262.

19-Mello JCP, Santos SC. Taninos. In: Simões CMO, Schenkel EP, Mello JCP, Mentz LA, Petrovick PR (Ed.). Farmacognosia: do produto natural ao medicamento. Porto Alegre: Artmed; 2017. p. 235-248.

20-Marques GS, Monteiro RPM, Leão WF, Lyra MAM, Peixoto MS, Rolim-Neto PJ, Xavier HS, Soares LAL. Avaliação de procedimentos para quantificação espectrofotométrica de flavonoides totais em folhas de Bauhinia forficata Link. Quim Nova. 2012;35:517-522. 
21-Alves IABS, Miranda HM, Barbosa AP, Randau KP, Soares LAL. Desenvolvimento e validação de metodologia analítica por espectrofotometria no visível para quantificação de taninos totais na casca do caule de Simarouba amara Aubl. Rev Árvore. 2015;39:37-47.

22-Wagner H. Synergy research: Approaching a new generation of phytopharmaceuticals. Fitoterapia. 2011;82:34-37.

23-Brazil. RE no 899, de 29 de Maio de 2003, Dispõe sobre o Guia para validação de métodos analíticos e bioanalíticos. Diário Oficial da República Federativa do Brasil, Brasília. DOU de 02/06/2003.

24-ICH. 2005. International Conference on Harmonisation Q2 (R1). Validation of analytical procedures: text and methodology.

25-Pueyo IU, Calvo MI. Assay conditions and validation of a new UV spectrophotometric method using microplates for the determination of polyphenol content. Fitoterapia. 2009;80:465-467.

26-Soares LAL, Farias MR. Qualidade de insumos farmacêuticos ativos. In: Simões CMO, Schenkel EP, Mello JCP, Mentz LA, Petrovick PR (Ed.). Farmacognosia: do produto natural ao medicamento. Porto Alegre: Artmed; 2017. p. 83-105.

27-Solón LGS, Costa LJL, Wanderley AG, Soares LAL, De Souza TP. Avaliação de agentes complexantes na quantificação de taninos totais em soluções extrativas de Schinus terebinthifolius R. e Psidium guajava L. Biofarma. 2007;2:275-281.

28-Verza SG, Kreinecker MT, Reis V, Henriques AT, González Ortega G. Avaliação da variáveis analíticas do método de Folin-Ciocalteau para a determinação do teor de taninos totais. Quím. Nova. 2007;30:815-820.

29-Adamczyk B, Adamczyk S, Smolander A, Kitunen V. 2011. Tannic acid and Norway spruce condensed tannins can precipitate various organic nitrogen compounds. Soil Biol Biochem. 2011;43:628-637.

30-Bueno FG, Machareth MAD, Panizzon GP, Lopes GC, Mello JCP, Leite-Mello EVS. Development of a UV/Vis spectrophotometric method for analysis of total polyphenols from Caesalpinia peltrophoroides Benth. Quim Nova. 2012;35:822-826.

31-Pelillo M, Cuvelier ME, Biguzzi B, Toschi TG, Berset C, Lercker G. Calculation of the molar absorptivity of polyphenols by using liquid chromatography with diode array detection: the case of carnosic acid. J Chromatogr A. 2004;1023:225-229.

32-Da Costa LM, Santos VA, Ohana DT, Lima ES, Pereira MM, Souza TP. Technological development of aqueous extracts from Calycophyllum spruceanum (Benth.) Hook. f. ex K. Schum., Rubiaceae, (mulateiro) using factorial design. Rev Bras Farmacogn. 2011;21:181-186.

33-Barros Neto B, Scarminio IS, Bruns RE. Como Fazer Experimentos: Aplicações na Ciência e na Indústria. 4th ed. UNICAMP, Campinas. 2010.

34-Monteiro JM, Lins Neto EMF, Amorim ELC, Strattmann RR, Araújo EL, Albuquerque UP. Tannin concentration in three simpatric medicinal plants from caatinga vegetation. Rev Árvore 2005;29:999-1005.

35-Ribani M, Bottoli CBG, Collins CH, Jardim ICSF, Melo LFC. Validação de métodos cromatográficos e eletroforéticos. Quím Nova. 2004;27:771-780.

36-Oliveira PTF, Alves GD, Silva FA, Silva FSB. Foliar bioactive compounds in Amburana cearensis (Allemao) A.C. Smith seedlings: Increase of biosynthesis using mycorrhizal technology. J Med Plants Res. 2015;9:712-718.

37-Dimech GS, Soares LAL, Ferreira MA, Oliveira AGV, Carvalho MC, Ximenes EA. Phytochemical and antibacterial investigations of the extracts and fractions from the stem bark of Hymenaea stigonocarpa Mart. ex Hayne and effect on ultrastructure of Staphylococcus aureus induced by hydroalcoholic extract. The Scientific World Journal. 2013;2013:1-8. 
38-Monteiro JM, Souza JSN, Lins Neto EM, Scopel K, Trindade EF. Does total tannin content explain the use value of spontaneous medicinal plants from the Brazilian semiarid region?. Rev Bras Farmacogn. 2014;24:116-123.

39-Blainski A, Lopes GC, Mello JCP. Application and Analysis of the Folin Ciocalteu Method for the Determination of the Total Phenolic Content from Limonium brasiliense L. Molecules. 2013;18:6852-6865.

40-Patra KC, Pareta SK, Harwansh RK, Kumar KJ. Traditional approaches towards standardization of herbal medicines - A review. J Pharm Sci Technol. 2010;2:372-379. 41-Tistaert C, Dejaegher B, Heyden YV. Chromatographic separation techniques and data handling methods for herbal fingerprints: A review. Anal Chim Acta, 2012;690:148-161.

42-Braz R, Wolf LG, Lopes GC Mello JCP. Quality control and TLC profile data on selected species commonly found in the Brazilian market. Rev Bras Farmacogn. 2012;22:1111-1118.

43-Brazilian Pharmacopoeia. 5 ed. Brasília: ANVISA, 2010.

44-British Pharmacopoeia. London: The Stationary Office, 2014.

45-DiCiaula MC, Lopes GC, Scarminio IE, Mello JCP. Optimization of solvent mixtures for extraction from bark of Schinus terebinthifolius by a statistical mixturedesign technique and development of a UV-VIS spectrophotometric method for analysis of total polyphenols in the extract. Quím. Nova. 2014;37:158-163

48-Araújo LBDC, Silva SL, Galvão MAM, Ferreira MRA, Araújo EL, Randau KP, Soares LAL. Total phytosterol content in drug materials and extracts from roots of Acanthospermum hispidum by UV-VIS spectrophotometry. Rev Bras Farmacogn. 2013;23:736-742.

46-Everette JD, Bryant QM, Green AM, Abbey YA, Wangila GW, Walker RB. Thorough Study of Reactivity of Various Compound Classes toward the FolinCiocalteau Reagent. J Agri Food Chem. 2010;58:8139-8144.

47-Kromidas S. Handbuch Validierung in der Analitik. Weinheim: Wiley-VCH. 2011. 